\title{
Al-Ijarah Al-Maushufah fi Al-Dzimmah in the Study of Islamic Financial Economics
}

\author{
Ahmad Syaichoni \\ Universitas Islam Negeri Sayyid Ali Rahmatullah Tulungagung, Indonesia \\ email: syaichoniahmad@gmail.com
}

\begin{abstract}
In the modern era like today, business transactions have developed along with technological developments. One form of development of business transactions is the modification of classic-contemporary contracts. One form of modification of the contract is the al-Ijarah al-Maushufah fi al-Dzimmah contract. This contract is developed for financing activities of Islamic financial institutions, especially the banking sector, and as an alternative to the financing scheme for infrastructure projects. This research aims to study the issue of alIjarah al-Maushufah fi al-Dzimmah in Islamic financial economics. This research is library research with a normative approach. The data analysis used is content analysis and critic analysis. According to the findings of this study, al-Ijarah alMaushufah fi al-Dzimmah is a contract development employed to suit the community's demands. The monotheism framework underpins the creation of al-Ijarah al-Maushufah fi al-Dzimmah in the study of Islamic financial economics. Tauhid is founded on evolutionary equilibrium and consciousness as a manifestation of monotheism in developing this product. The evolution and consciousness of Islamic banking products into new scientific jewels inside the treasures of Islamic financial economics is the theoretical implication of this research. Compared to previous research, the originality of this study is that the al-Ijarah al-Maushufah fi al-Dzimmah contract is reviewed in terms of Islamic financial economics with a tauhid framework.
\end{abstract}

Keywords: Al-Ijarah al-Maushufah fi al-Dzimmah; IMFZ; Tauhid Framework; Islamic Financial Economics

\begin{abstract}
Abstrak: Era modern seperti saat ini, transaksi bisnis mengalami pengembangan seiring dengan berkembangnya teknologi. Salah satu bentuk pengembangan transaksi bisnis adalah modifikasi akad klasik-kontemporer. Salah satu modifikasi akad tersebut adalah akad al-Ijarah al-Maushufah fi alDzimmah. Akad ini merupakan akad yang dikembangkan dalam kegiatan pembiayaan pada lembaga keuangan syariah, khususnya pada bidang perbankan dan merupakan produk alternatif skema pembiayaan yang digunakan untuk pembangunan proyek infrastruktur. Tujuan penelitian ini untuk menganalisis konsep al-Ijarah al-Maushufah fi al-Dzimmah dalam kajian ekonomi keuangan Islam. Penelitian ini menggunakan library research dengan pendekatan normatif. Analisis data yang digunakan adalah analisis isi dan analisis kritis. Hasil penelitian ini menunjukkan bahwa al-Ijarah al-Maushufah fi al-Dzimmah merupakan pengembangan akad yang digunakan untuk memenuhi kebutuhan masyarakat. Pengembangan al-Ijarah al-Maushufah fi al-
\end{abstract}

Economica: Jurnal Ekonomi Islam - Volume 11, Nomor 2 (2020) 
Ahmad Syaichoni

Dzimmah dalam kajian ekonomi keuangan Islam berdasarkan kerangka tauhid. Konsep tauhid dalam pengembangn produk ini didasarkan pada ekuilibrium evolusioner dan kesadaran sebagai manifestasi tauhid. Implikasi penelitian ini dari segi teoretis adalah pengembangan dan inovasi produk perbankan syariah menjadi khazanah keilmuan baru dengan dalam khazanah ekonomi keuangan Islam. Orisinalitas penelitian ini dibandingkan dengan penelitian sebelumnya adalah akad al-Ijarah al-Maushufah fi al-Dzimmah ditinjau dalam pandangan ekonomi keuangan Islam dengan kerangka tauhid.

Kata Kunci: Al-Ijarah al-Maushufah fi al-Dzimmah; IMFZ; Kerangka Tauhid; Ekonomi Keuangan Islam 


\section{Introduction}

Human activities in meeting their daily needs always depend on other humans. Humans must interact with each other to get what they need, both goods and services. Human interaction is regulated in Islam, known as fiqh muamalah, namely the sharia laws that regulate interactions between human beings related to the property ( $a l-m a l)$. One of the most critical discussions in muamalah is the study of contracts. Any transactions made by humans in obtaining goods and services are determined by what contract is used. Then the position of the contract here will determine whether the transaction is carried out following sharia principles or not.

In the modern era like today, business transactions have developed along with technological developments. The advancement of technology, mainly in communication, has resulted in a significant shift in the way people communicate (Athief 2019). One form of development of business transactions is the modification of classic-contemporary contracts. One form of modification of the contract is the al-Ijarah al-Maushufah fi al-Dzimmah contract. This contract is developed for financing activities of Islamic financial institutions, especially the banking sector and the non-banking sector. Nonbanking institutions play a significant role in the economy by providing funding, risk protection, temporary equity participation, investment, liquidity support, and new businesses (Sukardi, Fachrurazi, and Supriyanto 2019).

The fatwa of the National Sharia Council of the Indonesian Ulama Council Number 101/DSN-MUI/X/2016 regarding the al-Ijarah al-Maushufah fi alDzimmah agreement is issued proof that the nature of transactions in muamalah is constantly developing and flexible. Thus, the al-Ijarah alMaushufah fi al-Dzimmah contract adds to the variety of contracts in the muamalah fiqh treasury. As a result, the community has many contracts that can be tailored to the needs of life without violating sharia principles.

Economica: Jurnal Ekonomi Islam - Volume 11, Nomor 2 (2020) 
Ahmad Syaichoni

Table 1. Number of sharia bank akad usage

\begin{tabular}{lll}
\hline No & Contract & Percentage \\
\hline 1 & Murabaha & $45,65 \%$ \\
2 & Musyarakah & $43,93 \%$ \\
3 & Mudaraba & $3,75 \%$ \\
4 & Ijarah & $2,74 \%$ \\
5 & Qardh & $3,06 \%$ \\
6 & Istishna' & $0,60 \%$ \\
7 & Etc & $0,26 \%$ \\
\hline
\end{tabular}

Source: www.ojk.com, 2020

However, the development of Islamic bank products with various contract options did not have a significant impact. The use of Islamic bank products is comparable to the use of conventional bank products. Both corporations competed for the most satisfactory customer service and products. The Islamic banking industry has long been a fascinating topic to research. Especially when compared to the well before conventional banking industry conditions (Rusydiana and Hasib 2019). The use of Islamic bank contracts can be described in the following table 1 .

Based on the data at table 1, the use of the Murabaha contract still dominates the Islamic bank contract. This shows that people choose Islamic banks to carry out buying and selling activities. Moreover, Islamic bank products used to meet needs still use the buying and selling scheme, indicating that the product that is better known and easily understood by the public is the buying scheme. Meanwhile, Muslim scholars have raised concerns about the Murabaha financing mechanism. They suggest that Islamic banking, rather than removing interest and sharing risks, retains the practice of imposing interest under the term "Islam" (Maulidizen 2018).

This study aims to reveal the newest product of the Islamic bank al-Ijarah al-Maushufah fi al-Dzimmah as an alternative financing substitute for Murabaha for project infrastructure development. The existence of al-Ijarah 
al-Maushufah fi al-Dzimmah is expected to shift the use of Islamic bank contracts not only for Murabaha products but also for other products.

People who pick Murabaha items to satisfy their demands suggest that they are still unfamiliar with Islamic bank products. Therefore, Otoritas Jasa Keuangan's initiative of Islamic financial inclusion needs to be strengthened once more. People who understand and are willing to employ Islamic financial goods will see an increase in the usage of Islamic finance in Islamic bank products. Bank Indonesia defines inclusive finance as everyone's right to timely, efficient, informative, and competitive access to and complete services from financial institutions. Financial services are offered to all members of society, focusing on the week, productive poor, migrant workers, and people living in rural areas (Khasanah 2019). Because it Encourages a prosperous economy by providing all basic human necessities, eliminating all significant sources of difficulty and distress (poverty, unemployment, poor work chances, and others), and strengthening the moral and material quality of life (Aprianto 2017).

The belief is that Islamic finance may elegantly offer a coherent perspective for comprehending real economic problems and an authentic alternative to the foundations of economic management, which has sparked interest in the field. This is because the attainment of human prosperity is its estuary. This expectation is in keeping with the maqashid principle, which serves as a conceptual foundation for the entire development of Islamic finance, even down to the practical level (Wasyith 2017).

\section{Literature review}

Nasrul Fahmi Zaki Fuadi (2019), who describes the role and execution of the al-Ijarah al-Maushufah fi al-Dzimmah contract in Islamic banking products and services, is one of several research works that explore it. According to the findings, the al-Ijarah al-Maushufah fi al-Dzimmah contract was utilized for pivot house building, school costs, health costs, and hajj or umrah trip costs.

Economica: Jurnal Ekonomi Islam - Volume 11, Nomor 2 (2020) 
However, Murabaha contracts continue to dominate Islamic banking products in Indonesian Islamic financial institutions. As a result, Murabaha contracts are utilized wrongly in numerous areas due to their widespread use in practically all finance.

Furthermore, research was undertaken by Rega Felix and Lastuti Abu Bakar (2019) examines the possibilities for Islamic banking to apply al-Ijarah al-Maushufah fi al-Dzimmah. The application of al-Ijarah al-Maushufah fi alDzimmah for project infrastructure financing in Indonesia is a musharakahistishna'-ijarah contract scheme with a musharakah-istishna'-ijarah investment model. An ijarah masuhufah fi al-dzimmah contract is formed by combining the three contracts. However, the al-Ijarah al-Maushufah fi alDzimmah contract has not been able to establish Islamic banking products with the three combinations of these contracts and government laws. Therefore, government regulations heavily influence the application of this substance.

Moreover, Abu Taleb Mohammad Monawer and Akhtarzaite Abdul Azizi's (2015) research examines the constitutionality of the al-Ijarah alMaushufah fi al-Dzimmah agreement from various scholars' perspectives. The viewpoints of contemporary and classical experts on this contract are discussed in this study. Four schools of thought were approved in this research of al-Ijarah al-Maushufah fi al-Dzimmah. However, numerous points differed from present scholars. Based on fiqh research, this study provides a reference in product creation and contract innovation.

The following research, by Sri Apriliana Eka and Erawati Desi (2019), looks at assessing the fatwa al-Ijarah al-Maushufah fi al-Dzimmah applicability to the Go-Pay feature. According to this analysis, the Go-Pay system falls within the al-Ijarah al-Maushufah fi al-Dzimmah contract category. Because the sale and purchase transaction on the benefits of the object is carried out by transferring the benefits after payment has been made according to the specifications and criteria stated at the beginning of the order, the Go-Pay 
feature is included in the al-Ijarah al-Maushufah fi al-Dzimmah contract. This research is aimed at numerous aspects of the al-ljarah al-Maushufah fi alDzimmah, particularly in terms of wage provisions. Wages are set following the contract, and payment is given in cash.

Ahmad Syaichoni (2020) discussed the subject of al-Ijarah al-Maushufah fi al-Dzimmah. Al-Ijarah al-Maushufah fi al-Dzimmah is discussed from the standpoint of the current muamalah. The maslahah concept allows for the alIjarah al-Maushufah fi al-Dzimmah contract, which is founded on the maslahah theory, which is the form of establishing law, or maqashid sharia. The development of the al-Ijarah al-Maushufah fi al-Dzimmah product in the context of maqashid sharia aims to protect assets. As a result, maslahah-based products that follow the maqashid sharia objectives are popular in the development and innovation of sharia banking products.

In the study of fiqh, the ijarah contract has been discussed by the fuqaha, but later this contract was developed in combination with other contracts. The word ijarah comes from Arabic, which is the root word ajara which has several meanings; the first ajra means to rent out, second a'thahu ajran means he gives him a wage; and the third atsabahu means giving him a reward or reward for a job (Anis 1972). In other words, ijarah means rent, service, or compensation based on transactions carried out based on benefits in exchange for services (Hasan 2004). According to Sayyid Sabiq, ijarah is a type of contract to benefit from a replacement (Sabiq 1979).

The definition of ijarah is in terminology put forward by fiqh scholars; the first is the Hanafiyah ulema, which defines ijarah as a transaction or contract for a benefit accompanied by a compensation/reward (Al-Kasani 1978). According to the scholars, Shafi'iyah ijarah is a contract/transaction for the desired benefit, specific, mutable nature, and may be used for certain rewards (Al-Khatib 1978). Meanwhile, the Malikiyah and Hanabilah scholars gave the meaning of ijarah as the ownership of something that is allowed within a certain period in exchange for a reward (Qudamah 1982).

Economica: Jurnal Ekonomi Islam - Volume 11, Nomor 2 (2020) 
Ahmad Syaichoni

According to the Islamic Civil Code of the Kingdom of Jordan and the United Arab Emirates (UAE), as quoted by Muhammad, ijarah means allowing tenants to take advantage of rental goods for a certain period in exchange for a mutually agreed amount (Muhammad 2000). Meanwhile, Islamic jurists define ijarah as selling a benefit, utility, or service with a predetermined payment (Dewi 2007).

An ijarah contract is a contract for the sale of specific benefits, namely by transferring the use rights (benefits) of goods and services within a certain period with payment of wages without transferring ownership of the rental goods. The ijarah contract has developed along with the development of Islamic banks. Besides, to answer the various challenges and needs of the community in meeting their daily needs, a transaction concept is needed following what the community wants.

According to Hanafiyah, the pillars of ijarah are ijab and qabul, while according to the jumhur of scholars, four pillars must be fulfilled in the ijarah contract. First, 'aqidani are two people who have an affair, namely mu'jir or tenant and musta'jir or tenants. The second ritual is sighah (ijab and qabul). The third is ujrah, namely the rental price. The last pillar is a benefit (Zuhaily 1985).

Meanwhile, the fatwa of the National Sharia Council Number 09/DSNMUI/IV/2000 dated April 13, 2000, concerning Ijarah Financing stipulates the pillars of ijarah as follows: Statement of ijab and qabul. Contracting parties: consists of the lessor (lessor, asset owner, Sharia Financial Institution) and the lessee (lessee, the party who benefits from using the asset, the customer). Contract object: payment (lease) and benefits from the use of assets. The benefit of using an asset in an ijarah is the object of the contract that must be guaranteed because it is in harmony that must be fulfilled in exchange for the lease and not the asset itself. Sighat ijarah is a statement from the two contracting parties, either verbally or in other equivalent forms, 
utilizing an offer from the asset owner (sharia financial institution) and the receipt stated by the lessee (customer).

An ijarah contract is considered valid if it meets the following conditions: The willingness of both parties, if one of the contracting parties makes a transaction under coercion, the ijarah contract will be invalid. This voluntary requirement applies not only to sale and purchase contracts but also to ijarah contracts. Knowing the benefits of the goods that are the object of the transaction in the ijarah contract. Items that are used as the object of an ijarah transaction can be counted. The benefits of goods used as the object of ijarah transactions are permitted according to the shari'ah rules and not prohibited goods - the ability of musta'jir (tenants) to deliver or return goods (Sabiq 1979).

Al-Ijarah al-Maushufah fi al-Dzimmah transaction which is the latest model of the contract developed from the ijarah contract. This contract is a lease transaction for goods and services, but when the contract has only explained the criteria, specifications, characteristics, and quality of the object for lease. In the al-Ijarah al-Maushufah fi al-Dzimmah contract, the object for rent is still not in the assembly; only the specifications are explained to eliminate the presence of gharar. This transaction can be used in Islamic bank financing.

\section{Methods}

This study uses library research with a normative approach. In this study, we discuss the problems related to al-Ijarah al-Maushufah fi al-Dzimmah and various literature support. Examining library items as primary and secondary sources is used in this research method. Because this research comprises library research, the author collected data using documentation techniques in this case.

The primary source of this research is popular books were used to support the research and other several books about the theory of al-ljarah al-

Economica: Jurnal Ekonomi Islam - Volume 11, Nomor 2 (2020) 
Ahmad Syaichoni

Maushufah fi al-Dzimmah, which are: Fiqh al-Islami wa Adillatuhu, Fiqh Sunnah, Fatwa of the National Sharia Council of the Indonesian Ulama Council Number 101/DSN-MUI/X/2016 regarding the al-Ijarah al-Maushufah fi alDzimmah and Islamic Financial Economics.

Data analysis is one of the most important stages of research since it attempts to analyze and interpret the data obtained by researchers. This study uses the analytical approach to collect normative qualitative data in al-Ijarah al-Maushufah fi al-Dzimmah exposure and description. Content analysis and critical analysis were utilized in the data analysis. Content analysis is used to objectively and systematically reveal and describe the al-Ijarah al-Maushufah fi al-Dzimmah. At the same time, critical analysis is used to examine the data collected and seek to understand and provide explanations from the data collected comprehensively.

\section{Result and discussion}

The concept of al-Ijarah al-Maushufah fi al-Dzimmah is explained in the fatwa of the National Sharia Council Number 101/DSN-MUI/X/2016, which states that what is meant by the al-Ijarah al-Maushufah fi al-Dzimmah contract is a lease agreement for the benefits of an item (benefits of 'ain) and/or services ('amal) which at the time of the contract only mentioned the characteristics and specifications (quantity and quality).

Transactions where the object of the contract does not exist at the time of the agreement by only mentioning the criteria and specifications of the object in fiqh are known salam and istishna'. Fuqaha agree that salam and istishna' are allowed in fulfilling their daily needs. So the concept of the contract of alIjarah al-Maushufah fi al-Dzimmah can be equated with the concept of salam and istishna'.

In Indonesia al-Ijarah al-Maushufah fi al-Drimmah contract is a new product enacted at the end of 2016 through the Fatwa DSN-MUI No. 101/DSNMUI/X/2016. According to Fatwa, IMFD means a lease contract for the 
usufruct of an item ('ain) or service ('ama), which at the time of the contract only stipulates the characteristics, quantity, and quality (specifications). Classic scholars did not define al-Ijarah al-Maushufah fi al-Dzimmah, but the contract al-Ijarah al-Maushufah fi al-Dzimmah has been discussed in the chapter about the object that can be leased (Monawer and Aziz 2015).

Afterward, al-Ijarah al-Maushufah fi al-Dzimmah definition was given by contemporary scholars, including Abu Ghuddah, who provides the definition: al-Ijarah al-Maushufah fi al-Dzimmah is that wherein the mu'ajir (lessor) adheres to rendering usufruct stipulated thoroughly-by the qualities of salamenough to eliminate the potential conflict about the usufruct, whether the object of the object is such as leasing a stipulated car or human services such as tailoring and teaching (Monawer and Aziz 2015).

In general, financial services products in shari'ah microfinance institutions can be divided into two types; fundraising and financing (Wirdyaningsih 2007). Each of them is bound in their respective agreements as described below. Based on PBI No.7/46/PBI/2005 which is based on the DSN fatwa, fundraising activities are carried out on the principle/contract of wadi'ah and/or mudharabah. Meanwhile, for the distribution of funds/financing, can use sale and purchase contracts (Murabaha, istisna, and salam, (Fatwa Dewan Syariah Nasional No: 04/DSN-MUI/IV/2000 Tentang Murabahah 2000) lease agreements (ijarah and ijarah muntahiya bi al-tamlik) (Fatwa Dewan Syariah Nasional No: 09/DSN-MUI/IV/2000 Tentang Pembiayaan Ijarah 2000), qirad (Fatwa Dewan Syariah Nasional No: 07/DSNMUI/IV/2000 Tentang Pembiayaan Mudharabah (Qiradh) 2000) contracts, and profit-sharing contracts (musyarakah and mudharabah). (Fatwa Dewan Syariah Nasional No: 08/DSN-MUI/IV/2000 Tentang Pembiayaan Musyarakah 2000) The aspects of this Islamic banking product provide an alternative banking system that benefits both the community and banking, and prioritizes aspects of fairness in transactions, ethical investments, values of mutual 
Ahmad Syaichoni

support and fellowship in production, and avoids speculative activities in a transaction (Apriyanti 2018).

With all the tools in it, the presence of a sharia economy fulfills the community's actual needs. Moreover, sharia economics appears to be a hybrid economic system with a factor that neither capitalist nor socialist economies possess: the divine dimension where every economic action is intimately connected to principles of religion and piety based on God's revelation (Rohmati, Anggraini, and Widiastuti 2018).

Institutions in the financial sector are desperately needed to support capital in the productive sector. The concept of Islamic banking is one of them (Sabirin and Sukimin 2017). Therefore the product is trying to answer those needs. In the field of ijarah alone, for example, the shifting of product forms occurs several times. Ijarah muntahiyah bi al-tamlik and ijarah multijasa are evidence of the shift in the form of ijarah in the framework of meeting the community's economic needs.

The development of ijarah above is an attempt to adapt to modern business developments. Product development does not change in essence but instead adjusts to the public's value, shape, and a variant of economic needs. The economy as a constantly changing variable must also be guarded by the intellectual-mental readiness of Muslim economists to adapt to the shift in the paradigm of society in the economic field. The economy is a variable that is constantly moving and requires a solid framework to adapt to any changes.

As one of the countries with the largest Muslim population in the world, Indonesia should be the center for the development of Islamic finance in the world and not an impossible dream because Indonesia's potential to become a global player in Islamic finance is very large, considering that the large Muslim population is a potential industrial customer. Furthermore, with the investment-grade category obtained by Indonesia, Islamic finance will increase investor interest in investing in the Islamic financial industry sector 
and Indonesia's abundant natural resources as the underlying transactions of the Islamic financial industry.

Several factors are driving the increasing performance of the Islamic financial institution industry in Indonesia, both in funding and lending financing, namely: The extensive network of Islamic financial institution offices makes access more accessible, thereby affecting customer interest in using Islamic financial institution products. A literacy and inclusion program for Islamic financial institutions to stakeholders regarding the products and services to increase further awareness and interest in using Islamic financial institution services. Efforts to improve service excellence of Islamic financial institutions in meeting the increasingly competitive competition for conventional banking services, namely, by utilizing increasingly advanced financial technology (fintech), improving and enhancing the quality of Automated Teller Machines (ATM) services, mobile banking, and internet banking and others. The existence of DSN-MUI regulations and fatwas on the products and services of Islamic financial institutions in providing legal certainty and increasing the activity of the Islamic financial market, such as UU No.21 of 2008 concerning Islamic Banking, UU No.19 of 2008 concerning State Sharia Securities (Sukuk), UU No.42 of 2009 concerning the Third Amendment of UU No.8 of 1983 concerning Value Added Tax of Goods and Services and the existence of a fatwa on the halalness of products and services that Islamic financial institutions present to stakeholders, namely the DSNMUI fatwa. The birth of the Sharia Banking Law and the DSN-MUI fatwa, which took part in overseeing the operations of financial institutions, will encourage the development of Islamic financial institutions both in service and presentation of products and services so that they continue to innovate (Hayat 2014).

Al-Ijarah al-Maushufah fi al-Dzimmah can be applied in homeownership financing transactions. Before issuing the fatwa of the National Sharia Council of the Indonesian Ulama Council on al-Ijarah al-Maushufah fi al-Dzimmah,

Economica: Jurnal Ekonomi Islam - Volume 11, Nomor 2 (2020) 
Ahmad Syaichoni

there was already a contract used to finance homeownership using the musyarakah mutanaqishah (MMQ) contract. With the issuance of a fatwa on al-Ijarah al-Maushufah fi al-Dzimmah, this contract can become a complementary contract or combined with the musyarakah mutanaqishah (MMQ) contract. The al-Ijarah al-Maushufah fi al-Dzimmah contract can be used with the musyarakah mutanaqishah contract when the house, an asset, is still under construction using pure ijarah; it cannot be applied. This is because the benefits of the goods ('ain' benefits) still cannot be handed over to the tenant when the contract takes place. In contrast to the case, if using the alIjarah al-Maushufah fi al-Dzimmah contract, rental transactions can be carried out even though the rented house (the item for rent) is still not there.

Infrastructure is the foundation of a country's economic development. The infrastructure is necessary for the functioning of the economy and society (Yescombe 2007). The use of al-Ijarah al-Maushufah fi al-Dzimmah is a form of sharia bank contract development. This contract development aims to provide many choices for the community in managing their finances. Al-Ijarah alMaushufah fi al-Dzimmah is the right contractor to use for infrastructure development and state projects. With various benefits obtained by customers, the market share of Islamic banks will increase. Besides, the Islamic banking industry can contribute to Indonesia's total financial assets.

\section{Al-ljarah al-maushufah fi al-dzimmah in islamic financial economics}

The study of the conceptual relationships and applied relationships between economic and financial theory is called financial economics. In the conventional understanding, the study of economic and financial theory contrasts with Islam. Because they have different characteristics, conventional economic and financial theory is irrelevant and can be accepted in Islamic economics. Theoretical studies in economics are positivistic, implying they are based on rationality and do not allow religious intervention. This is in contradiction to the qualities of Islamic economics, which combine reason and 
revelation from God. As a result, religion, which is based on God's revelation, impacts economic and financial pursuits (Furqani 2019).

In particular, the concept of Zakat in economics is not included in conventional economics because Zakat is based on revelation. Therefore, Zakat is a religious doctrine that should be excluded from economic considerations. Unlike Islamic economics, which considers the notion of Zakat to be a part of economics. Because Islam oversees all elements of human existence, including economic operations, all economic activities must follow Islamic guidelines (Karim 2015).

Moreover, Islamic doctrine influences how the concept and development of financial economics are founded on Islamic laws in the study of financial economics. So, Islamic financial economics refers to economic and financial operations governed by Islamic principles, rooted in moral and ethical consciousness, and conceptualized using welfare standards and maslahah in all things (Choudhury 2016).

In introducing the nature of Islamic financial economics, especially Islamic banking, in today's innovation and institutional environment, Islamic financial economics extends the concept of epistemological monotheism. To build an Islamic financial economy, epistemological monotheism is founded on evolutionary equilibrium and consciousness. Thus, monotheism is manifested in all notions of development based on evolutionary equilibrium and consciousness, as described in the Qur'an (Choudhury 2016).

As part of Islamic financial institutions, Islamic banking aims to be a tool that humans, particularly Muslims, can utilize to perform transactions and investments. As a result, Islamic banking must tailor its offerings to the community's commercial and investment needs. Al-Ijarah al-Maushufah fi alDzimmah is one of the investment items established. This Islamic financial product can be viewed in terms of evolutionary equilibrium and consciousness.

Economica: Jurnal Ekonomi Islam - Volume 11, Nomor 2 (2020) 
Ahmad Syaichoni

The term "evolutionary equilibrium" refers to a state of equilibrium in the surrounding environment (Choudhury 2016). According to al-Ijarah alMaushufah fi al-Dzimmah, the development of Islamic banking products is an endeavor to reconcile investment demands for both the short and long term, small and big size investments, and investments in investments the financial and real sectors. Therefore, the rise of al-Ijarah al-Maushufah fi al-Dzimmah items could involve large-scale state projects and infrastructure development, unlike the ijarah contract, which is simply for using an item or service's benefits.

In developing al-Ijarah al-Maushufah fial-Dzimmah products, the concept of consciousness means that Islamic banking products are developed based on conscious purpose, objectivity, and maslahah (Choudhury 2016). Al-Ijarah al-Maushufah fi al-Dzimmah is an ijarah development product intended to construct new projects or infrastructure. From the perspective of its objective, the al-Ijarah al-Maushufah fi al-Dzimmah product was created to meet investment and business needs in the banking industry to compete with other banks. The requirement for adjustments and improvements in banking to boost public interest in using Islamic banking services is the objectivity in designing this product. As a result, we require a product that will be acceptable to all stakeholders and investors.

From the perspective of the maslahah, al-Ijarah al-Maushufah fi alDzimmah can assist Islamic banking, Islamic financial institutions, and investors. This product can be promoted in Islamic banking for large-scale development initiatives, with the banks benefiting from the results. This product adds a variety of investment options to Islamic financial institutions, which is projected to raise the level of Islamic financial inclusion, a program of Otoritas Jasa Keuangan. For investors, the emergence of this commodity can be exploited as an interest-free and haram investment. 


\section{Conclusion}

Transactions with the al-Ijarah al-Maushufah fi al-Dzimmah agreement following the DSN-MUI fatwa are a form of contract development to meet the community's needs. In the development of al-Ijarah al-Maushufah fi alDzimmah products, the concept of consciousness means that Islamic banking products are developed based on conscious purpose, objectivity, and maslahah. From the perspective of its objective, the al-Ijarah al-Maushufah $f i$ al-Dzimmah product was created to meet investment and business needs in the banking industry to compete with other banks. The requirement for adjustments and improvements in banking to boost public interest in using Islamic banking services is the objectivity in designing this product. The model of the al-Ijarah al-Maushufah fi al-Dzimmah contract needs to be developed so that it can be helpful for Islamic banking to increase the level of Islamic financial inclusion in the community.

\section{References}

Al-Kasani. 1978. “Al-Bada'i Al-Shana'i." In. Beirut: Dar al-Fikr.

Al-Khatib, Al-Syaibani. 1978. “Mughni Al-Muhtaj.” In. Beirut: Dar al-Fikr.

Anis, Ibrahim. 1972. “Al-Mu'jam Al-Wasith.” In. Kairo: Dar al-Ihya' al-Turats.

Aprianto, Naerul Edwin Kiky. 2017. "Kontruksi Sistem Jaminan Sosial Dalam Perspektif Ekonomi Islam." Economica: Jurnal Ekonomi Islam 8 (2): 23762. https://doi.org/10.21580/economica.2017.8.2.1334.

Apriliana, Eka Sri, and Desi Erawati. 2019. "Tinjauan Penerapan Fatwa DSN MUI No. 101 Tahun 2016 Tentang Al-Al-Ijarah al-Maushufah fi alDzimmah Terhadap Fitur Go-Pay." At-Taradhi: Jurnal Studi Ekonomi X (2): 157-67. https://doi.org/10.18592/at-taradhi.v10i2.3290.

Apriyanti, Hani Werdi. 2018. "Model Inovasi Produk Perbankan Syariah Di Indonesia." Economica: Jurnal Ekonomi Islam 9 (1): 83-104. https://doi.org/10.21580/economica.2018.9.1.2053.

Athief, Fauzul Hanif Noor. 2019. "Embedding Crowdfunding Structure in Islamic Venture Capital for SMEs Development." Economica: Jurnal

Economica: Jurnal Ekonomi Islam - Volume 11, Nomor 2 (2020) 
Ahmad Syaichoni

Ekonomi $\quad$ Islam $\quad 10 \quad$ (1): $\quad 1-28$. https://doi.org/10.21580/economica.2019.10.1.3186.

Choudhury, Masudul Alam. 2016. Islamic Financial Economy and Islamic Banking. New York: Routledge. https://doi.org/10.4324/9781315590011.

Dewi, Gemala. 2007. Aspek-Aspek Hukum Dalam Perbankan Dan Perasuransian Syariah Di Indonesia. Cetakan Ke. Jakarta: Kencana.

Fatwa Dewan Syariah Nasional No: 04/DSN-MUI/IV/2000 Tentang Murabahah. 2000.

Fatwa Dewan Syariah Nasional No: 07/DSN-MUI/IV/2000 Tentang Pembiayaan Mudharabah (Qiradh). 2000.

Fatwa Dewan Syariah Nasional No: 08/DSN-MUI/IV/2000 Tentang Pembiayaan Musyarakah. 2000.

Fatwa Dewan Syariah Nasional No: 09/DSN-MUI/IV/2000 Tentang Pembiayaan Ijarah. 2000.

Felix, Rega, and Lastuti Abubakar. 2019. "Application of Al-Ijarah AlMaushufah Fi Al-Dzimmah for Infrastructure Project Financing in Indonesia." $\quad$ Yuridika $\quad 35 \quad$ (1): 129. https://doi.org/10.20473/ydk.v35i1.9021.

Fuadi, Nasrul Fahmi Zaki. 2019. "Implementasi Akad Al-Ijarah Al-Maushufah Fi Al-Dzimmah Sebagai Alternatif Pembiayaan Di Lembaga Keuangan Syariah Indonesia." Indonesian Journal of Islamic Literature and Muslim Society 4 (2): 211-32. https://doi.org/10.22515/islimus.v4i2.1750.

Furqani, Hafas. 2019. "What Is Islamic Economics? The View of Muhammad Baqir Al-Sadr." Jurnal Ekonomi \& Keuangan Islam 5 (2): 63-71. https://doi.org/10.20885/jeki.vol5.iss2.art3.

Hasan, Habib Nazir \& Muh. 2004. Ensiklopedi Ekonomi Dan Perbankan Syari'ah. Bandung: Kaki Langit.

Hayat, Hayat. 2014. "Globalisasi Perbankan Syariah: Tinjauan Teoritis Dan Praktis Dalam Menghadapi Masyarakat Ekonomi Asean 2015." HunafA: Jurnal Studia Islamika 11 (2): 293. https://doi.org/10.24239/jsi.v11i2.358.293-314.

Karim, Adiwarman. 2015. Ekonomi Mikro Islami. 5th ed. Jakarta: Raja Grafindo Persada. 
Khasanah, Miftakhul. 2019. "Equivalence of Islamic Financial Literation Index with Islamic Financial Inclusion Index in The Islamic Banking Sector: A Case Study of DIY Society." Economica: Jurnal Ekonomi Islam 10 (2): 25582. https://doi.org/10.21580/economica.2019.10.2.3241.

Maulidizen, Ahmad. 2018. "Literature Study on Murābahahah Financing in Islamic Banking in Indonesia." Economica: Jurnal Ekonomi Islam 9 (1): 25-49. https://doi.org/10.21580/economica.2018.9.1.2411.

Monawer, Abu Talib Mohammad, and Akhtarzaite Abd Aziz. 2015. "Dispute Over the Legality of Al-Ijarah Al-Mawsufah Fi Al- Dhimmah: A Survey of Fiqhi Opinions." ISRA International Journal of Islamic Finance 7 (1): 4974.

Muhammad. 2000. Sistem Dan Prosedur Operasional Bank Syariah. Yogyakarta: UII Press.

Qudamah, Ibnu. 1982. “Al-Mughni.” In. Riyadh: al-Haditsah.

Rohmati, Dani, Rachmasari Anggraini, and Tika Widiastuti. 2018. "Maqāṣid AlSharīah Sebagai Landasan Dasar Ekonomi Islam." Economica: Jurnal $\begin{array}{lllll}\text { Ekonomi } & \text { Islam } & 9 & \text { (2): }\end{array}$ https://doi.org/10.21580/economica.2018.9.2.2051.

Rusydiana, Aam Slamet, and Fatin Fadhilah Hasib. 2019. "Islamic Banking Selection Criteria: Case in Indonesia Using Analytic Network Process." Economica: Jurnal Ekonomi Islam 10 (1): 165-88. https://doi.org/10.21580/economica.2019.10.1.2846.

Sabiq, Sayyid. 1979. Fiqh Al-Sunnah.

Sabirin, Sabirin, and Dini Ayuning Sukimin. 2017. "Islamic Micro Finance Melati: Sebuah Upaya Penguatan Permodalan Bagi Pedagang Pasar Tradisional." Economica: Jurnal Ekonomi Islam 8 (1): 27-53. https://doi.org/10.21580/economica.2017.8.1.1824.

Sukardi, Budi, Fachrurazi Fachrurazi, and Supriyanto Supriyanto. 2019. "Sharia Maqashid's Inclusive Performance and Contribution to The Sharia Non-Bank Financial Industry in Indonesia." Economica: Jurnal $\begin{array}{lllll}\text { Ekonomi } & \text { Islam } & 10 & \text { (2): }\end{array}$ https://doi.org/10.21580/economica.2019.10.2.4325.

Syaichoni, Ahmad. 2020. "Al-Ijarah al-Maushufah fi al-Dzimmah Dalam Kajian Muamalah Kontemporer." Jurnal Syntax Transformation 1 (10): 668-75. https://doi.org/10.46799/\%25J.Vol1.Iss10.173.

Economica: Jurnal Ekonomi Islam - Volume 11, Nomor 2 (2020) 
Ahmad Syaichoni

Wasyith, Wasyith. 2017. "Beyond Banking: Revitalisasi Maqāșid Dalam Perbankan Syariah.” Economica: Jurnal Ekonomi Islam 8 (1): 1-25. https://doi.org/10.21580/economica.2017.8.1.1823.

Wirdyaningsih. 2007. Bank Dan Asuransi Islam Di Indonesia. Jakarta: Prenada Media.

Yescombe, E.R. 2007. Public Private Partnership: Principles of Policy And Finance. London: Elsevier.

Zuhaily, Wahbah. 1985. Al-Fiqh Al-Islamiy Wa Adillatuhu. Damsyiq: Dar al-Fikr. 